SCIENTIFIC ARTicle

\title{
Methods of potassium contents evaluation in the substrate solution and gerbera leaves
}

Fernanda Ludwig ${ }^{1 *}$; Dirceu Maximino Fernandes ${ }^{2}$; Amaralina Celoto Guerrero ${ }^{3}$; Guilherme Amaral Ferreira ${ }^{4}$; Valeria Pohlmann ${ }^{5}$

\begin{abstract}
Several authors report that potassium $(\mathrm{K})$ is the nutrient absorbed in greater amounts by gerbera plants. Thus, objective of determining the concentration of Kin the solution of substrates for growing potted gerbera, quantified by the Cardy Horiba C-131 and an atomic absorption spectrophotometer, correlating them with each other and with the plant leaf content. The experiment was carried out in a greenhouse. The experimental design was in randomized complete blocks using a $5 \times 2$ factorial scheme $(5$ substrates/2 cultivars) and four replications. Cherry and Red gerbera cultivar seedlings with four final leaves were transplanted into pots, filled with the substrates and acclimated for 30 days. After acclimation, the $\mathrm{K}$ content in the substrate solution extracted by the "PourThru" methodology was evaluated every two weeks using the Cardy Horiba C-131 portable ion meter and an atomic absorption spectrophotometer, as well as the $\mathrm{K}$ content in the leaves of gerbera plants. The solution of the commercial substrate had higher concentrations of $\mathrm{K}$ in relation to the others in the two forms of measurement, which is directly related to the high initial contents of the nutrient in this substrate. This is directly related to the high initial K contents in the substrate. Greater values of K were obtained for the cultivar Red, both in the solution and in the leaves. The K concentration of the substrate solution cultured with gerbera plants quantified by the Cardy Horiba C-131 and atomic absorption spectrophotometry correlated significantly with each other and showed a low correlation with the content of this nutrient in the plant tissue.
\end{abstract}

Keywords: Gerbera jamesonii, fertilization, plant nutrition.

\section{RESUMO}

Comparação de métodos de avaliação dos teores de potássio na solução do substrato e folhas de gérbera Vários autores relatam que o potássio (K) é o nutriente absorvido em maiores quantidades pelas plantas de gérbera. Assim, objetivou determinar a concentração de K na solução de substratos no cultivo de gérbera de vaso, quantificado pelo Cardy Horiba C-131 e espectrofotometria de absorção atômica e correlacioná-los entre si e com o teor foliar na planta. O experimento foi realizado em casa de vegetação. O delineamento experimental utilizado foi o de blocos ao acaso em esquema fatorial $5 \times 2$ ( 5 substratos/2 cultivares) e quatro repetições. As mudas de gérbera cultivares Cherry e Red, com quatro folhas definitivas foram transplantadas em vasos preenchidos com os substratos e aclimatadas durante 30 dias. Após a aclimatação, avaliou-se quinzenalmente o teor de K na solução do substrato extraída pela metodologia do "PourThru", e o teor foliar de potássio das plantas de gérbera, utilizando-se o medidor de íons portátil Cardy Horiba C-131 e o espectrofotômetro de absorção atômica. A solução do substrato comercial apresentou maiores concentrações de $\mathrm{K}$ em relação aos demais nas duas formas de medição, o que está relacionado diretamente com os elevados teores iniciais do nutriente nesse substrato. Valores maiores de $\mathrm{K}$ foram obtidos para a cultivar Red, tanto na solução quanto nas folhas. A concentração de K da solução do substrato cultivado com plantas de gérbera envasada quantificada pelo Cardy Horiba C-131 e pela espectrofotometria de absorção atômica correlacionaram-se significativamente entre si, e apresentaram baixa correlação com o teor desse nutriente nas folhas.

Palavras-chave: Gerbera jamesonii, adubação, nutrição de plantas.

\footnotetext{
${ }^{1}$ Universidade Estadual do Rio Grande do Sul (UERGS), Unidade em Santa Cruz do Sul, Santa Cruz do Sul-RS, Brazil.*Corresponding author: fernanda-ludwig@uergs.edu.br.

${ }^{2}$ FCA/UNESP, Departamento de Solos e Recursos Ambientais, Botucatu-MG, Brazil.

${ }^{3}$ Sebrae-SP, Brazil.

${ }^{4}$ Centro de Citricultura Sylvio Moreira - APTA, Cordeirópolis-SP, Brazil.

${ }^{5}$ Universidade Federal de Santa Maria, Santa Maria-RS, Brazil.
} 


\section{Introduction}

Gerbera is an herbaceous plant, perennial, with capitulum inflorescence, belonging to the Asteraceae family and original from South Africa (Mercurio, 2002). It's internationally known as cut flower, flower in vase and garden lining (Jeong et al., 2009). Recently introduced in Brazil, it still needs several studies that contribute for its productive quality (Ludwig et al., 2014).

The species has been more largely studied as cut flower, there being only little available information about cultivation techniques as flower in vase and, thereby, the management of the production factors is realized several times in an empirical way by farmers (Ludwig et al., 2010), mainly fertilization (Guerrero et al., 2012).

Potassium $(\mathrm{K})$ is an essential nutrient for plant growth and development (Schachtman e Shin, 2007). Its importance in photosynthesis, osmoregulation, enzymatic activation, protein synthesis and maintenance of the anion/cation equilibrium in plants is well documented (Marschner, 1986; Bhandal and Malik, 1988; Zhao et al., 2001; Kanai et al., 2007). Potassium deficiency can result in negative impacts, such as reduction of photosynthesis, transpiration (Degl'innocenti et al., 2009; Kanai et al., 2011) and sucrose transport from leaf to consumer organs such as flowers (White and Karley, 2010), and leaf area reduction (Zhao et al., 2001; Gerardeaux et al., 2010). These impacts, integrated, can result in even bigger losses in floriculture due to possible damages in the agricultural products appearance, considerably depreciating it and compromising its commercialization.

The most demanded macronutrient by Gerbera plants is $\mathrm{K}$, being essential its supply, mainly in the flowering stage (Mercurio, 2002; Ludwig et al., 2008; Guerrero et al., 2012; Guerrero et al., 2016). It becomes important to study methods of $\mathrm{K}$ content determination in Gerbera plants, due to its high importance in species growth and development. In this context, quick tests are potential alternatives (Mota et al., 2014).

Short cycle plants cultivated in reduced volume vases, being the case of Gerbera, need frequent nutritional supply to result in a recommended aspect for commercialization. For the production success, it's important to realize the nutritional evaluation in the most agile way possible. To test the substrate solution is a precise way to monitor the real rhizosphere nutrition, thus helping in the fertilization program adaptation (Yao et al., 2008).
Knowing quick and practical methodologies of ionic concentration determination of the substrate solution is important to make less onerous the verification of the available nutrients for plants. Among the available methods for solution obtaining, stands out the "PourThru", that's based in the solution volume displacement, in order to obtain samples of available nutrients for plants in the lixiviated solution (Cavins et al., 2000). It's a nondestructive method and there is the possibility of realization even in the greenhouse.

Allied to this, there is the perspective of quick tests utilization with good accuracy through the use of portable measurers, resulting in a relevant time and costs reduction for the nutritional monitoring of the applied nutritive solution. According to Mota et al. (2014), quick tests present high correlation with nitrogen and $\mathrm{K}$ amounts in Gerbera leaves, presenting the advantages of practicality and determination speed, making easy the substrate fertility monitoring by farmers and technicians, and making it easier to take eventual decisions on fertilization adjustments.

Thus, the present work was conducted with the aim of determining the $\mathrm{K}$ concentration in substrate solution in Gerbera cultivation in vases, quantified by Cardy Horiba C-131 and atomic absorption spectrophotometry, and to correlate them with each other and with the leaf content.

\section{Material and Methods}

Experiment was conducted in greenhouse covered in arch with transparent plastic of $150 \mu \mathrm{m}$ of thickness, laterals of white grille, transparent plastic curtain and paved with concrete, with total area of $168 \mathrm{~m}^{2}(7.0 \times 24.0 \mathrm{~m})$ and 2.6 $\mathrm{m}$ of height. Average temperature and relative air humidity inside greenhouse were $23{ }^{\circ} \mathrm{C}$ and $63 \%$, respectively, during experimental period.

The experimental design used was randomized blocks, applying factorial schedule $5 \times 2 \quad(5$ substrates and 2 cultivars) with 4 reps. The 5 substrates used were elaborated with different formulations (Table 1) composed by red soil (RS) from Oxisol; pine bark (PB); granulated coconut fiber (GCF); mixed coconut fiber (MCF); composition 1 (C1) corresponding to $40 \%$ pine bark $+30 \%$ vermiculite $+30 \%$ carbonized rice hull; composition 2 (C2) with $75 \%$ pine bark $+25 \%$ pine aciculae and the commercial substrate with $70 \%$ pine bark $+15 \%$ peat $+15 \%$ vermiculite. 
Table 1. Formulations of each substrate used in the growth and development of gerbera.

\begin{tabular}{|c|c|c|c|}
\hline & \multicolumn{3}{|c|}{ Substrates } \\
\hline
\end{tabular}

RS: red soil; PB: pine bark; C1: composition 1; C2: composition 2; GCF: granulated coconut fiber; MCF: mixed coconut fiber.

Substrates were selected through chemical and physical analyses previously realized. Chemical characteristics of electrical conductivity (EC) and $\mathrm{pH}_{1: 5}$ (Brasil, 2007) and macronutrients and micronutrients ${ }_{1: 1,5}$ (Sonneveld and
Elderen, 1994), as well as the physical characteristics of density (Brasil, 2007) and water retention (De Boodt and Verdonck, 1972), C/N relation and organic matter (Raij et al., 2001) of substrates are presented in Table 2 .

Table 2. Chemical and physical characteristics of substrates used in the experiment.

\begin{tabular}{|c|c|c|c|c|c|}
\hline Characteristics & Substrate 1 & Substrate 2 & Substrate 3 & Substrate 4 & Substrate 5 \\
\hline $\mathrm{EC}_{1: 5}\left(\mathrm{dS} \mathrm{m}^{-1}\right)$ & 0.54 & 0.49 & 0.26 & 0.28 & 0.48 \\
\hline $\mathrm{pH}_{1: 5 \text { (initial) }}$ & 5.13 & 4.81 & 5.74 & 5.74 & 7.58 \\
\hline $\mathrm{pH}_{1: 5 \text { (final) }}$ & 5.42 & 4.86 & 5.63 & 5.59 & 6.89 \\
\hline $\mathrm{OM}(\%)$ & 19.00 & 28.00 & 38.00 & 33.00 & 34.00 \\
\hline $\mathrm{C} / \mathrm{N}$ & 10.55 & 15.55 & 21.11 & 18.33 & 18.88 \\
\hline $\mathrm{K}_{1: 1.5}\left(\mathrm{mg} \mathrm{L}^{-1}\right)$ & 70.25 & 86.00 & 45.43 & 56.70 & 176.25 \\
\hline $\mathrm{Ca}_{1: 1.5}\left(\mathrm{mg} \mathrm{L}^{-1}\right)$ & 52.40 & 84.98 & 3.57 & 22.83 & 21.63 \\
\hline $\operatorname{Mg}_{1: 1.5}\left(\mathrm{mg} \mathrm{L}^{-1}\right)$ & 50.15 & 57.60 & 12.13 & 24.45 & 12.83 \\
\hline $\mathrm{Cu}_{1: 1.5}\left(\mathrm{mg} \mathrm{L}^{-1}\right)$ & 0.01 & 0.02 & 0.06 & 0.03 & 0.06 \\
\hline $\mathrm{Fe}_{1: 1.5}\left(\mathrm{mg} \mathrm{L}^{-1}\right)$ & 0.38 & 0.62 & 5.57 & 1.76 & 1.83 \\
\hline $\mathrm{Mn}_{1: 1.5}\left(\mathrm{mg} \mathrm{L}^{-1}\right)$ & 0.19 & 2.48 & 0.20 & 0.38 & 0.84 \\
\hline $\mathrm{Zn}_{1: 1.5}\left(\mathrm{mg} \mathrm{L}^{-1}\right)$ & 0.04 & 0.11 & 0.06 & 0.06 & 0.08 \\
\hline Total Porosity- TP (\%) & 78.79 & 80.62 & 84.28 & 89.18 & 83.51 \\
\hline Solids (\%) & 21.21 & 19.38 & 15.72 & 10.82 & 16.49 \\
\hline Aeration Space - AS (\%) & 23.50 & 19.33 & 12.76 & 17.15 & 21.10 \\
\hline Available Water - AW (\%) & 28.74 & 29.40 & 37.34 & 35.80 & 32.90 \\
\hline Remaining Water - RW (\%) & 26.48 & 31.89 & 34.62 & 36.23 & 29.50 \\
\hline Humid Density $\left(\mathrm{kg} \mathrm{m}^{-3}\right)$ & 750.00 & 850.00 & 690.00 & 590.00 & 530.00 \\
\hline Dry Density $\left(\mathrm{kg} \mathrm{m}^{-3}\right)$ & 538.00 & 540.00 & 450.00 & 298.00 & 340.00 \\
\hline
\end{tabular}

It was used Gerbera seedlings (Gerbera jamesonii L) with four definitive leaves, from Cherry and Red cultivars, belonging to series "Dark Eyes" from Sakata ${ }^{\circledR}$ company. They were planted in vases with capacity for $1 \mathrm{~L}(11.5 \mathrm{~cm}$ of depth, $13 \mathrm{~cm}$ of superior basis and $9 \mathrm{~cm}$ of inferior basis), being previously fulfilled according to the humid density of each used substrate, until total vase volume, allowing particle accommodation.

Plants were acclimated during 30 days, disposed on wooden bench (1.2 m of width, $12.0 \mathrm{~m}$ of length and $0.8 \mathrm{~m}$ of height) under removable thermo-reflective mesh (Aluminet ${ }^{\circledR}$ ) disposed in the superior part of the greenhouse, keeping luminous intensity close to 25,000 lx. Finished the acclimation, vases were spaced $25 \mathrm{~cm}$ by $25 \mathrm{~cm}$ and distributed on two wooden benches, under maximum luminous intensity of 50,000 1x. Experimental evaluation started immediately after acclimation period, being the results presented in days after acclimation (DAA).

Fertigation management was based on the daily weight of the vases. Necessary amount for water reposition was stablished by difference between the obtained mass in vase capacity ( $100 \%$ of available water) and the minimum retention capacity, or permanent wilting point. From these measurements, it was assessed the corresponding mass to $50 \%$ and $25 \%$ of the available water in the vase. 
Nutritive solution was adapted from that utilized by specialized farmer and adapted by Ludwig (2010) and presented the following composition in $\mathrm{mg} \mathrm{L}^{-1}: 121 \mathrm{~N}^{-\mathrm{NO}_{3}}$ , $12 \mathrm{~N}^{-\mathrm{NH}_{4}^{+}}, 92 \mathrm{~K}^{+}, 24 \mathrm{P}, 175 \mathrm{Ca}, 27 \mathrm{Mg}$ and $39 \mathrm{~S}, 0,19$ $\mathrm{B}, 0,08 \mathrm{Cu}, 2,74 \mathrm{Fe}, 0,19 \mathrm{Mn}, 0,04 \mathrm{Mo}$ and $0,08 \mathrm{Zn}$ in vegetative stage and $168 \mathrm{~N}-\mathrm{NO}_{3}^{-}, 41 \mathrm{~N}^{-\mathrm{NH}_{4}^{+}}, 303 \mathrm{~K}^{+}, 35$ $\mathrm{P}, 105 \mathrm{Ca}, 45 \mathrm{Mg}$ and $55 \mathrm{~S}, 0,19 \mathrm{~B}, 0,08 \mathrm{Cu}, 2,74 \mathrm{Fe}, 0,19$ $\mathrm{Mn}, 0,04 \mathrm{Mo}$ and $0,08 \mathrm{Zn}$ in the reproductive. It was used the following nutrients: calcium nitrate, potassium nitrate, magnesium sulfate, monoammonium phosphate (MAP), yellow kristalon ${ }^{\circledR}$ (13-40-13), orange kristalon ${ }^{\circledR}$ (6-12$36)$, with micros ${ }^{\circledR}(7,26 \%$ Fe EDTA, $1,82 \% \mathrm{Cu}$ EDTA, $0,73 \%$ Zn EDTA, $1,82 \%$ Mn EDTA, 1,82\% Bo, 0,36 Mo, $0,36 \mathrm{Ni})$ and rexolin ${ }^{\circledR}(11 \% \mathrm{Fe})$. Solution was managed for EC maintenance in $2.0 \mathrm{dS} \mathrm{m}^{-1}$ in the vegetative stage and $2.5 \mathrm{dS} \mathrm{m}^{-1}$ in the reproductive. The reproductive stage started 30 days after acclimation, coinciding with inflorescence emission.

Fortnightly, substrate solution was collected using "PourThru" methodology (Cavins et al., 2000), adapted by Ludwig et al. (2017), to quantify K content. For this determination, it was used the Cardy Horiba C-131 portable ions measurer and atomic absorption spectrophotometry, being the values expressed in $\mathrm{mg} \mathrm{L}^{-1}$. New Gerbera leaves, completely expanded, were collected at the same period and in the same vases in which it was applied the above mentioned method. Leaves were washed, dried in drying oven with forced ventilation at $65^{\circ} \mathrm{C}$ until constant weight, milled in miller type "Wiley" and analyzed for K content, following Malavolta et al. (1997) methodology.

Obtained results were submitted to variance analysis by $\mathrm{F}$ test and means compared by Tukey test at $5 \%$, when significant, using the Sisvar statistical program (Ferreira, 2011). Correlation was stablished by the Pearson method between $\mathrm{K}$ contents obtained by different methodologies.

\section{Results and Discussion}

Potassium content obtained in substrates solutions, using the portable measurer Cardy Horiba C-131 (Table 3) and with the atomic absorption spectrophotometer (Table 4), varied significantly in all analyzed epochs.

Table 3. Average of $\mathrm{K}$ concentration in the solution of the substrate obtained by the use of cardy. depending on the substrates and gerbera cultivars.

\begin{tabular}{|c|c|c|c|c|}
\hline & \multicolumn{4}{|c|}{ DAA } \\
\hline & 15 & 29 & 43 & 50 \\
\hline Substrate & \multicolumn{4}{|c|}{ - } \\
\hline 1 & $110.9 \mathrm{~b}$ & $110.0 \mathrm{~b}$ & $266.3 \mathrm{~b}$ & $362.5 \mathrm{~b}$ \\
\hline 2 & $123.6 \mathrm{~b}$ & $123.8 \mathrm{~b}$ & $242.5 \mathrm{~b}$ & $407.5 \mathrm{~b}$ \\
\hline 3 & $99.4 \mathrm{~b}$ & $102.5 \mathrm{~b}$ & $268.8 \mathrm{~b}$ & $330.0 \mathrm{~b}$ \\
\hline 4 & $126.8 \mathrm{~b}$ & $89.1 \mathrm{~b}$ & $236.3 \mathrm{~b}$ & $373.8 \mathrm{~b}$ \\
\hline 5 & $280.0 \mathrm{a}$ & $216.3 \mathrm{a}$ & $368.8 \mathrm{a}$ & $596.3 \mathrm{a}$ \\
\hline \multicolumn{5}{|l|}{ Cultivar } \\
\hline Red & $165.0 \mathrm{~A}$ & 138.1 & $302.5 \mathrm{~A}$ & 424.5 \\
\hline Cherry & $131.3 \mathrm{~B}$ & 118.6 & $250.5 \mathrm{~B}$ & 403.5 \\
\hline CV $(\%)$ & 24.0 & 24.4 & 14.6 & 15.5 \\
\hline
\end{tabular}

DAA: Days after acclimation. Means followed by same lower case in column (substrates) and upper case (cultivars) do not differ to each other by Tukey test at $5 \%$.

Average K contents obtained by Cardy Horiba C-131 didn't show interaction of cultivars with substrates, while K content obtained by atomic absorption spectrophotometry showed this interaction in evaluated dates, except for 29
DAA. The highest concentrations were found in solution of the substrate 5 (commercial), which relates directly with the most elevated total content determined in substrate 5 , corresponding to $176.25 \mathrm{mg} \mathrm{L}-1$ (Table 2). 
Table 4. Average of $\mathrm{K}$ concentration in the substrate solution obtained by atomic absorption spectrophotometry. as a function of substrates and gerbera cultivars.

\begin{tabular}{|c|c|c|c|c|c|c|c|}
\hline & \multicolumn{7}{|c|}{ K atomic absorpion } \\
\hline & \multicolumn{7}{|c|}{ DAA } \\
\hline & \multicolumn{2}{|c|}{15} & 29 & \multicolumn{2}{|c|}{43} & \multicolumn{2}{|c|}{50} \\
\hline & Red & Cherry & & Red & Cherry & Red & Cherry \\
\hline Substrate & \multicolumn{7}{|c|}{ 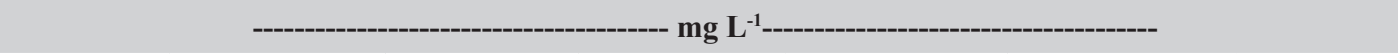 } \\
\hline 1 & $73.9 \mathrm{bA}$ & $67.5 \mathrm{cA}$ & $106.4 \mathrm{~b}$ & $256.5 \mathrm{bA}$ & $231.0 \mathrm{bA}$ & $260.4 \mathrm{bcA}$ & $228.3 \mathrm{bA}$ \\
\hline 2 & $123.7 \mathrm{bA}$ & $76.8 \mathrm{cB}$ & $114.3 \mathrm{~b}$ & $286.9 \mathrm{bA}$ & $204.1 \mathrm{bB}$ & $298.3 \mathrm{bA}$ & $262.8 \mathrm{bA}$ \\
\hline 3 & $79.7 \mathrm{bA}$ & $58.2 \mathrm{cA}$ & $94.3 \mathrm{~b}$ & $255.8 \mathrm{bA}$ & $254.8 \mathrm{bA}$ & $187.5 \mathrm{cB}$ & $252.8 \mathrm{bA}$ \\
\hline 4 & $106.7 \mathrm{bB}$ & $195.5 \mathrm{bA}$ & $79.4 \mathrm{~b}$ & $222.2 \mathrm{bA}$ & $260.0 \mathrm{bA}$ & $280.1 \mathrm{bA}$ & $220.3 \mathrm{bA}$ \\
\hline 5 & $310.5 \mathrm{aA}$ & $291.5 \mathrm{aA}$ & $211.4 \mathrm{a}$ & $390.8 \mathrm{aA}$ & $389.3 \mathrm{aA}$ & $405.1 \mathrm{aA}$ & $455.8 \mathrm{aA}$ \\
\hline \multicolumn{8}{|l|}{ Cultivar } \\
\hline Red & & & 124.4 & & & & \\
\hline Cherry & & & 117.8 & & & & \\
\hline CV (\%) & \multicolumn{2}{|c|}{18.7} & 31.9 & \multicolumn{2}{|c|}{11.9} & \multicolumn{2}{|c|}{15.2} \\
\hline
\end{tabular}

DAA: Days after acclimation. Means followed by same lower case in column (substrates) and upper case (cultivars) do not differ to each other by Tukey test at $5 \%$.

The initial substrate fertilization is a fundamental factor for the nutrient management supplied during the culture cycle and, specifically, for the cultivation in commercial substrate (Table 2), for which the nutritive solution can be reformulated, reducing the $\mathrm{K}$ concentrations. The validity and consistency of this affirmation are evident when analyzed the leaf content of K (Table 5) that didn't show significant increase in plants conducted in this substrate, compared to the others. In research with substrates for citrus rootstock production, Schäfer et al. (2006) verified the variation in results that different commercial substrates can result, when evaluating two commercial substrates.

Table 5. Mean K contents in gerbera leaves as a function of substrates and cultivars.

\begin{tabular}{|c|c|c|c|c|c|}
\hline & \multicolumn{5}{|c|}{$K$ content in vegetal tissue } \\
\hline & \multicolumn{5}{|c|}{ DAA } \\
\hline & 15 & \multicolumn{2}{|c|}{29} & \multirow[t]{2}{*}{43} & \multirow[t]{2}{*}{50} \\
\hline & & Red & Cherry & & \\
\hline Substrate & \multicolumn{5}{|c|}{ 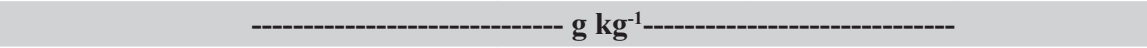 } \\
\hline 1 & 38.9 & 36.9 c A & $40.5 \mathrm{ab} \mathrm{A}$ & $36.9 \mathrm{c}$ & 40.8 \\
\hline 2 & 42.2 & $39.8 \mathrm{bc} \mathrm{A}$ & $36.4 \mathrm{~b} \mathrm{~A}$ & $40.1 \mathrm{bc}$ & 43.4 \\
\hline 3 & 43.2 & $39.1 \mathrm{bc} \mathrm{B}$ & 46.4 a A & $41.6 \mathrm{bc}$ & 45.9 \\
\hline 4 & 43.4 & 53.1 a A & $44.9 \mathrm{ab} B$ & $46.4 \mathrm{ab}$ & 47.1 \\
\hline 5 & 39.7 & $47.2 \mathrm{ab} \mathrm{A}$ & $39.8 \mathrm{ab} B$ & $50.6 \mathrm{a}$ & 48.8 \\
\hline \multicolumn{6}{|l|}{ Cultivar } \\
\hline Red & $43.7 \mathrm{~A}$ & & & 43.0 & 44.7 \\
\hline Cherry & $39.3 \mathrm{~B}$ & & & 43.2 & 45.7 \\
\hline CV (\%) & 9.5 & 10.5 & & 12.3 & 18.6 \\
\hline
\end{tabular}

DAA: Days after acclimation. Means followed by same lower case in column (substrates), upper case (cultivars) for 29 DAA, and lower case in column, comparing cultivars, independent of substrate, do not differ to each other by Tukey test at $5 \%$.

In reproductive stage, evaluations about $\mathrm{K}$ content in nutritive solution demonstrated that $\mathrm{K}$ concentration was elevated, and even with the EC management of the nutritive solution, its values in the commercial substrate were much higher than the others (Table 3 and 4 ), reaffirming the importance of the adequate initial fertilization to prevent problems by excess of nutrients. Specifically for the Gerbera cultivars Red and Cherry, it wasn't registered excessive absorptions that could result in visual symptoms of plant toxicity, but yes, huge amounts of daily applied $\mathrm{K}$ in fertigation and not used by plants. 
The extracted solutions from substrates with two cultivars and quantified using the portable measurer varied in relation to the $\mathrm{K}$ concentration, at 15 and 43 DAA, when were observed bigger values for Red cultivar (Table 3 ). When the solution was analyzed by atomic absorption, the highest concentration for Red occurred in substrate 2 at 15 and 43 DAA and Cherry in substrate 4 at 15 DAA and in substrate 3 at 50 DAA (Table 4).

In spite of the higher $\mathrm{K}$ concentration in substrate solution were found in substrates in which Red variety was cultivated, in most part of evaluations with both methodologies, leaf content of this cultivar was higher (Table 5). The higher content, however, is due to the lower average dry leaf mass production (Table 5) from Red cultivar plants $(11.76 \mathrm{~g})$ in relation with that from Cherry (13.38 g), resulting in bigger $\mathrm{K}$ content. These data lead to infer that the substrate evaluation must come together with the vegetal tissue analysis, for the correct comprehension of the interaction between substrate and plant.

The $\mathrm{K}$ contents in Gerbera leaves are variable in literature. In study developed by Damasceno et al. (2011), K content in Gerbera leaves cultivated in vases and fertigated with treated effluents from domestic sewage, with and without mineral fertilization, varied from 39.11 to $40.23 \mathrm{~g}$ $\mathrm{kg}^{-1}$, with no visual symptoms of deficiency of this nutrient in leaves. According to Mercurio (2002), the adequate K content for Gerbera is found in the range between 30.6 e $36.4 \mathrm{~g} \mathrm{~kg}^{-1}$, being these values inferior to the observed (Table 5). However, this nutrients requirement difference among Gerbera cultivars, and among vase and cut plants, contribute to the observed variation, being that Mota et al. (2014), in work with Gerbera of vase, Cherry cultivar, registered average $\mathrm{K}$ content of 43 and $38 \mathrm{~g} \mathrm{~kg}^{-1}$, at 28 and 56 days after spacing, respectively. The utilization of the nutritional referential standard for Gerbera production can induce to errors in fertilization management, being that visual injuries in floriculture are extremely harmful in comparison with other crops. Therefore, it becomes relevant the determination of the ideal nutrient ranges for each type of production, cultivar, or cultivars with similar characteristics.

The average relation between the obtained values by Cardy Horiba C-131 and by atomic absorption spectrophotometry is showed in Image 1. It's observed that the majority of the values are situated between 100 and $200 \mathrm{mg} \mathrm{L}^{-1}$. Both methodologies presented $\mathrm{K}$ values very close to each other, even when the contents were higher.

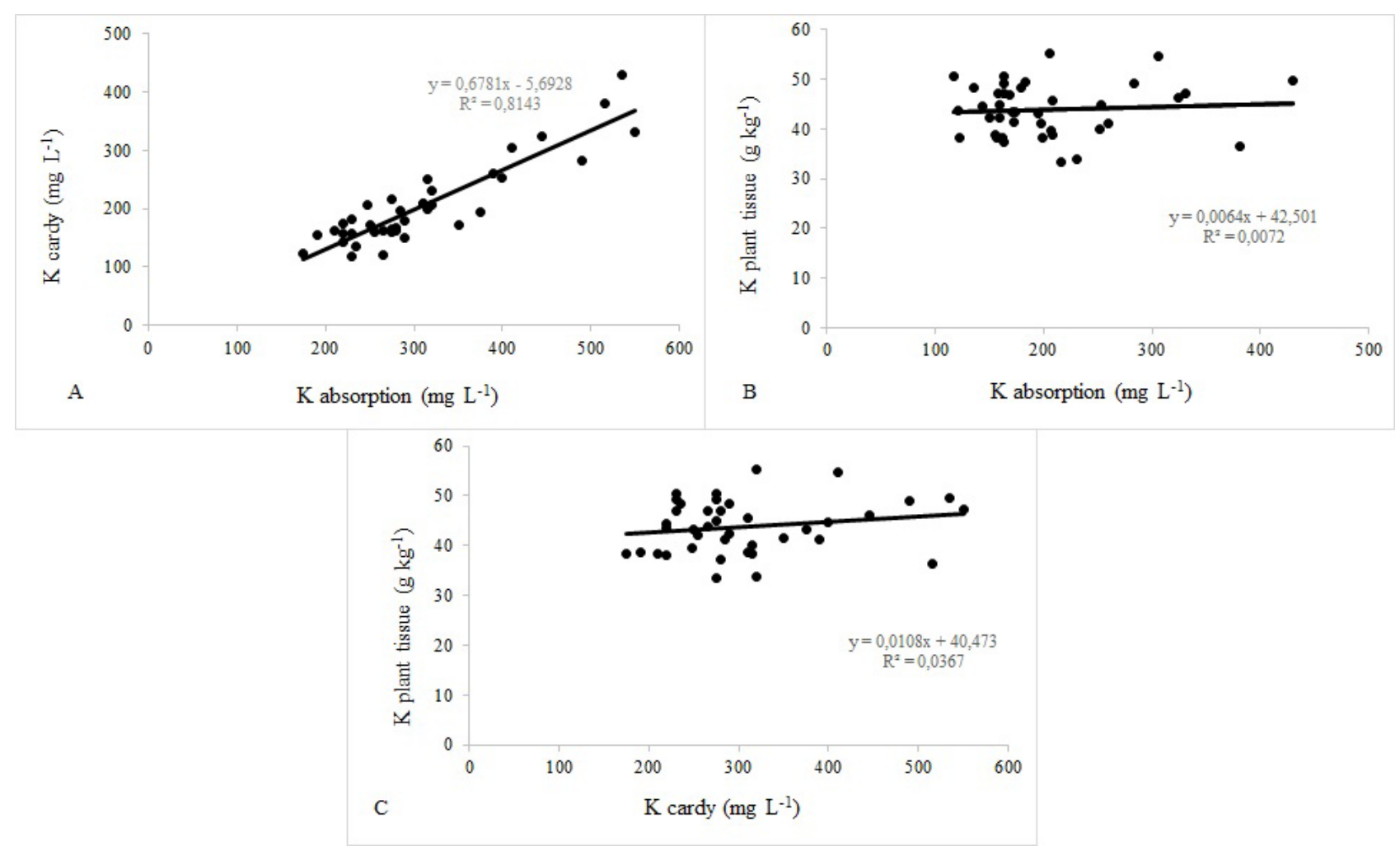

Figure 1. Mean values of $\mathrm{K}$ of the substrate solution determined by the cardy and atomic absorption spectrophotometry and the gerbera plant tissue. 
Correlation between $\mathrm{K}$ content from substrate solution measured with Cardy Horiba C-131 and atomic absorption spectrophotometry was highly significant $\left(\mathrm{r}^{2}: 0.95^{* *}\right)$, validating the determination methodologies. Evaluating tomato plants, Folegati et al. (2005) also registered high correlation between $\mathrm{K}$ contents measured with the portable ion measurer Horiba (CIM) and with flame photometry, highlighting that the use of portable measurer is adequate to evaluate the ionic concentration in soil or substrate solution, giving quick and precise measurements for the fertigation management. The use of portable extractors is viable, with acceptable precision, speeding up the nutritional disequilibrium diagnose and helping with the fertigation management (Silva et al., 2003).

The portable measurers are being used for different purposes and are obtaining success in its objective. In vines, there was significate correlation between $\mathrm{K}$ content in the chemical analysis of the petiole with the $\mathrm{K}$ content in the petiole sap obtained with the help of a portable measurer (Tecchio et al., 2011). In Gerbera plants, quick tests showed high correlation with total $\mathrm{N}$ and $\mathrm{K}$ (Mota et al., 2014).

Low significate correlations were registered between leaf nutrient content and substrate solution quantified by Cardy Horiba C-131 ( $\left.\mathrm{r}^{2}: 0.38^{*}\right)$ and from vegetal tissue and substrate solution quantified by atomic absorption spectrophotometry $\left(\mathrm{r}^{2}: 0.39^{*}\right)$. Mota et al. (2014), however, obtained high correlation $\left(\mathrm{r}^{2}: 0.72\right)$ between $\mathrm{K}$ from extractive solution with Cardy Horiba C-131 and $\mathrm{K}$ content in aerial part of Cherry cultivar. The differences between the results can be explained by the initial $\mathrm{K}$ values in substrate, mainly in substrates 2 and 5 (Table 2) that previously provided a huge part of the plant nutrient demand, impairing the correlation between the obtained by "PourThru" method and the one found in vegetal tissue. Other factors can jeopardize the reading fidelity through the portable measurers, such as the $\mathrm{K}$ forms applied (Kallenbach, 2000) and the interference of other ions, which can affect the possible correlations with contents found in plants by the traditional methods, there being the necessity of equipment calibration at each measuring. For vines, Tecchio et al. (2011) concluded being possible the use of portable measurers of $\mathrm{N}$ and $\mathrm{K}$, provided that there are studies to improve the calibration of them. Thus, the use of portable measurers is a viable alternative to determine the $\mathrm{K}$ content in substrates solution, being an easier and quicker method than the standard one. However, there is still the necessity of new studies with other portable measurers in Gerbera plants.

\section{Conclusion}

The $\mathrm{K}$ concentration of the substrate solution from Gerbera cultivated in vase, quantified by Cardy Horiba C-131 and by atomic absorption spectrophotometry, correlated positive and significantly with each other, but showed low correlation with the leaf $\mathrm{K}$ content.

\section{Author Contribution}

F.L. ${ }^{0000-0001-6641-9996}$,A.C.G. and G.A.F. ${ }^{0000-0001-9498-0676}$ : conception and design of the research, conducting of the research, obtaining data, analyze and interpretation of data, statistical analysis, write of manuscript; D.M.F.: advisor, conception and design of the research, analyze and interpretation of data, write and critically analyses of manuscript; V.P.: data analyze, write and critically analyses of manuscript.

\section{Acknowledgments}

The authors are thankful to the Coordenação de Aperfeiçoamento Pessoal de Nível Superior - CAPES for the doctoral scholarship granted to the first author and to the Conselho Nacional de Desenvolvimento Científico e Tecnológico - CNPq, for the scholarship granted to the advisor.

\section{References}

BHANDAL, I.S.; MALIK, C.P. Potassium estimation, uptake, and its role in the physiology and metabolism of flowering plants. International Review of Cytology, v.110, p.205-254, 1988. DOI: https://doi.org/10.1016/ S0074-7696(08)61851-3

BRASIL. Instrução Normativa n.17, de 21 de maio de 2007. Aprova os Métodos Analíticos Oficiais para Análise de Substratos e Condicionadores de Solos. Diário Oficial da União, Brasília, 24 maio. 2007. Seção 1, p.8.

CAVINS, T.J.; WHIPKER, B.E.; FONTENO, W.C.; HARDEN, B.; McCALL, I.; GIBSON, J.L. Monitoring and managing $\mathrm{pH}$ and $\mathrm{EC}$ using the PourThru extraction method. Raleigh: Horticulture Information, 2000. 17p.

DAMASCENO, L.M.O; JÚNIOR, A.S.A.; GHEY, H.R.; DIAS, N.S.; SILVA, C.P. Composição nutricional foliar da gérbera irrigada com efluente doméstico tratado. Revista Caatinga, v.24, n.2, p.121-128, 2011.

De BOODT, M; VERDONCK, O. The physical properties of the substrates in horticulture. Acta Horticulturae, v.26, p.37-44. 1972. DOI:http://dx.doi.org/ 10.17660/ActaHortic.1972.26.5

DEGL'INNOCENTI, E.; HAFSI, C.; GUIDI, L.; NAVARIIZZO, F. The effect of salinity on photosynthetic activity in potassium-deficient barley species. Journal of Plant Physiology, v.166, n.18, p.1968-1981, 2009. DOI: https:// doi.org/10.1016/j.jplph.2009.06.013

FERREIRA, D.F. Sisvar: a computer statistic analysis system. Ciência e Agrotecnologia, v.35, n.6, p.10391042, 2011. DOI: http://dx.doi.org/10.1590/S141370542011000600001 
FOLEGATTI, M.V.; BLANCO, F.F.; BOARETTO, R.M.; BOARETTO, A.E. Calibration of cardy-ion meters to measure nutrient concentrations in soil solution and in plant sap. Scientia Agricola, v.62, n.1, p.8-11, 2005. DOI: http://dx.doi.org/10.1590/S0103-90162005000100002

GERARDEAUX,E.;JORDAN-MEILLE,L.;CONSTANTIN, J.; PELLERIN, S.; DINGKUHN, M. Changes in plant morphology and dry matter partitioning caused by potassium deficiency in Gossypium hirsutum (L.). Environmental and Experimental Botany, v.67, n.3, p.451-459, 2010. DOI: https://doi.org/10.1016/j.envexpbot.2009.09.008

GUERRERO, A.C.; FERNANDES, D.M.; LUDWIG, F. Acúmulo de nutrientes em gérbera de vaso em função de fontes e doses de potássio. Horticultura Brasileira, v.30, n.2, p.201-208, 2012. DOI: http://dx.doi.org/10.1590/ S0102-05362012000200004

GUERRERO, A.C.; FERNANDES, D.M.; LUDWIG, F.; FERREIRA, G. A. Teor e acúmulo de micronutrientes em gérbera de vaso em função de fontes e doses de potássio. Revista Verde de Agroecologia e Desenvolvimento Sustentável, v.11, n.4, p.26-33, 2016.DOI: http://dx.doi. org/10.18378/rvads.v11i4.4461

JEONG, K.Y.; WHIPKER, B.; MCCALL, I.; GUNTER, C.; FRANTZ, J. Characterization of nutrient disorders of gerbera hybrid 'Festival Light Eye Pink'. Acta Horticulturae, v.843, p.177-182, 2009. DOI: http://dx.doi. org /10.17660/ActaHortic.2009.843.22

KALLENBACH, R.L. Field use of an ion-specific electrode to measure the potassium concentration in alfalfa. Crop Science, v.40, n.3, p.772-777, 2000. DOI: http://dx.doi. org/10.2135/cropsci2000.403772x

LUDWIG, F.; FERNANDES, D.M.; MOTA, P.R.D.; VILLAS BÔAS, R.L. Macronutrientes em cultivares de gérbera sob dois níveis de fertirrigação. Horticultura Brasileira, v.26, n.1, p.68-73, 2008. DOI: http://dx.doi. org/10.1590/S0102-05362008000100013

LUDWIG, F; FERNANDES, D.M.; MOTA, P.R.D.; VILLAS BOAS, R.L. Crescimento e produção de gérbera fertirrigada com solução nutritiva com solução nutritiva. Horticultura Brasileira, v.28, n.4, p.424-429, 2010. DOI: http://dx.doi.org/10.1590/S0102-05362010000400008

LUDWIG, F.; FERNANDES, D.M.; GUERRERO, A.C.; VILLAS BÔAS, R.L. Características dos substratos na absorção de nutrientes e na produção de gérbera de vaso. Horticultura Brasileira, v.32, n.2, p.184-189, 2014. DOI: http://dx.doi.org/10.1590/S0102-05362014000200011

LUDWIG, F.; GUERRERO, A.C.; FERREIRA, G.A.; FERNANDES, D.M.; VILLAS BÔAS, R.L. Adapting of "PourThru" for evauation of substrates with diferente granulometries. Ornamental Horticulture, v.23, n.1, p.22-29, 2017. DOI: https://doi.org/10.14295/oh.v23il.911
MALAVOLTA, E.; VITTI, G.C.; OLIVEIRA, S.A. Avaliação do estado nutricional das plantas: princípios e aplicações. Piracicaba: Potafos, 1997. 319p.

MARSCHNER, H. Mineral nutrition of higher plants. London: Acad Press, 1986.672p.

MERCURIO, G. Gerbera cultivation in greenhouse. The Netherlands: Schreurs. 2002. 206p.

MOTA, P.R.D'A.; VILLAS BÔAS, R.L.; LUDWIG, F.; FERNANDES, D.M.; FOLEGATTI, M. V. Portable meters for nutritional assessment in plants of gerbera fertigated with electrical conductivity levels. Revista Brasileira de Engenharia Agrícola e Ambiental, v.18, n.3, p.258262. 2014. DOI: http://dx.doi.org/10.1590/S141543662014000300003

KANAI, S.; OHKURA, K.; ADU-GYAMFI, J.J.; MOHAPATRA, P.K.; NGUYEN, N.T.; SANEOKA, H.; FUJITA, K. Depression of sink activity precedes the inhibition of biomass production in tomato plants subjected to potassium deficiency stress. Journal of Experimental Botany, v.58, n.11, p.2917-2928, 2007. DOI: http://dx.doi. org/10.1093/jxb/erm149

KANAI, S.; MOGHAIEB, R.E.; EL-SHEMY, H.A.; PANIGRAHI, R.; MOHAPATRA, P.K.; ITO, J.; NGUYEN, N.T.; SANEOKA, H.; FUJITA, K. Potassium deficiency affects water status and photosynthetic rate of the vegetative sink in green house tomato prior to its effects on source activity. Plant Science, v.180, n.2, p.368-374, 2011. DOI: http://dx.doi.org/10.1016/j.plantsci.2010.10.011

RAIJ, B. van.; ANDRADE, J.C.; CANTARELLA, H.; QUAGGIO, J.A. (Eds.) Análise química para avaliação da fertilidade do solo. Campinas: Instituto Agronômico, 2001. 285p.

SCHACHTMAN, D.P.; SHIN, R. Nutrient sensing and signaling: nPKS. Annual Review Plant Biology, v.58, p.47-69, 2007. DOI: http://dx.doi.org/10.1146/annurev. arplant.58.032806.103750

SCHÄFER. G.; SOUZA, P.V.D.; KOLLER, O.C.; SCHWARS, S.F. Desenvolvimento vegetativo inicial de porta-enxertos cítricos cultivados em diferentes substratos. Ciência Rural, v.36, n.6, p.1723-1729, 2006. DOI: http:// dx.doi.org/10.1590/S0103-84782006000600009

SILVA, E.F.F.; DUARTE, S.N.; FOLEGATTI, M.V.; ROJAIS, E.G. Utilização de testes rápidos e extratores de solução do solo na determinação de nitrato e potássio. Engenharia Agrícola, v.23, n.3, p.460-467, 2003.

SONNEVELD, C; ELDEREN, C.W. Chemical analysis of peaty growing media by means of water extraction. Communication on Soil Science and Plant Analysis, v.25, n. 19-20, p. 3199-3208. 1994. DOI: http://doi. org/10.1080/00103629409369258 
TECCHIO, M.A.; MOURA, M.F.; PAIOLI-PIRES, E.J.; TERRA, M.M.; TEIXEIRA, L.A.J.; SMARSI, R.C. Teores foliares de nutrientes, índice relativo de clorofila e teores de nitrato e de potássio na seiva do pecíolo na videira Niagara rosada. Revista Brasileira de Fruticultura, v.33, n.2, p.649-659. 2011. DOI: http://dx.doi.org/10.1590/S010029452011005000058

WHITE, P.J.; KARLE, A.J. Potassium. In: HELL, R.; MENDEL, R-R (eds) Cell biology of metals and nutrients. Springer, Heidelberg, 2010. p.199-224.
YAO, H.Y.; R.S.; HO, S.B.; CHANG, Y.C.A. Adapting the Pour-through medium extraction method to Phalaenopsis grown in sphagnum moss. Hortscience, v.43, n.7, p.21672170, 2008.

ZHAO, D.; OOSTERHUIS, D.M.; BEDNARZ, C.W. Influence of potassium deficiency on photosynthesis, chlorophyll content, and chloroplast ultrastructure of cotton plants. Photosynthetica, v.39, n.1, p.103-109, 2001. DOI: https://doi.org/10.1023/A:1012404204910 